\title{
CONCENTRATIONS OF ${ }^{65} \mathrm{Zn}$ IN MARINE FOODSTUFFS \\ AND PACIFIC COASTAI RESIDENTS*
}

T. H. Essig**, G. W. R. Endres, J. K. Soldat and J. F. Honstead***

\author{
Battelle \\ Pacific Northwest Laboratories \\ Richland, Washington 99352
}

\author{
March 1972
}

*This paper is based on work performed under United States Atomic Energy Commission Contract AT(45-1)-1830.

**Currently employed by the USAEC, DREP, Washington, D. C. *** Deceased. 


\section{DISCLAIMER}

This report was prepared as an account of work sponsored by an agency of the United States Government. Neither the United States Government nor any agency Thereof, nor any of their employees, makes any warranty, express or implied, or assumes any legal liability or responsibility for the accuracy, completeness, or usefulness of any information, apparatus, product, or process disclosed, or represents that its use would not infringe privately owned rights. Reference herein to any specific commercial product, process, or service by trade name, trademark, manufacturer, or otherwise does not necessarily constitute or imply its endorsement, recommendation, or favoring by the United States Government or any agency thereof. The views and opinions of authors expressed herein do not necessarily state or reflect those of the United States Government or any agency thereof. 


\section{DISCLAIMER}

Portions of this document may be illegible in electronic image products. Images are produced from the best available original document. 


\section{CONCENTRATIONS OF ${ }^{65} \mathrm{Zn}$ IN MARINE FOODSTUFFS \\ AND PACIFIC COASTAL RESIDENTS*}

T. H. Essig,** G. W. R. Endres, J. K. Soldat and J. F. Honstead***

Battelle

Pacific Northwest Laboratories

Richland, Washington 9.9352

March 1972

I. INTRODUCTION

The Hanford plant, located on the Columbia River in southeastern Washington, for a number of years discharged small concentrations of radionuclides into the river with the once-through cooling water from the production reactor. Most of the radionuclides were short-lived activation products but a few nuclides persisted in the river all the way down to the Pacific Ocean. Small amounts of radionuclides from Hanford have been found in fin fish such as salmon, but by far the greatest concentrations occur in the various shellfish taken from sites near the mouth of the Columbia River. Two of these nuclides are biologically active $\left({ }^{65} \mathrm{zn}\right.$ and $\left.{ }^{32} \mathrm{P}\right)$ and have been routinely measured in seafood.

This paper describes tle study of ${ }^{65} \mathrm{zn}$ in people living in two coastal communities in oregon and washington in the spring of 1970 and the fall of 1971, and the relationship between their body burdens and their seafood intake. The study was designed to obtain data about both the average for the communities and the maximum seafood consumers.

*This paper is based on work performed under United States Atomic Energy Commission Contract AT (45-1)-1830. **Currently employed by the USAEC, DREP, Washington, D. C. $* * *$ Deceased. 
For purposes of this paper, the word seafood will mean Pacific shelifish, as it is assumed that negligible contributions to the radioactivity in the diet of coastal residents were made by fin fish or non-local seafoods.

The objectives of the study during spring 1970 were: First, to determine the seafood consumption habits of a population living. in a coastal seafood-producing community; second, to measure the ${ }^{65} \mathrm{Zn}$ body burden of people ingesting this radionuclide with seafood (shellfish); and third, to evaluate the sufficiency of available metabolic uptake models for describing the assimillation and retention of ${ }^{65} \mathrm{zn}$ from these foodstuffs.

A second study of the ${ }^{65} \mathrm{zn}$ levels in the coastal community residents was conducted in the fall of 1971 to determine the effects of the shut down of the older (once-through cooled) Hanford production reactors earlier in that year. For this part of the program, the same people counted in the spring of 1970 were recounted wherever possible so as to measure individual changes in ${ }^{65} \mathrm{zn}$ body burdens.

\section{EXPERIMENTAL DESIGI}

\section{A. Populations surveyed}

The two communities chosen for the study are within a reasonable distance from the mouth of the columbia River. Both were known to have measurable concentrations of radioactive zinc in locally-obtained seafoods, which had been routinely monitored during the operations at Hanford. The location of the selected communities relative to the Hanford plant is shown in Fig. 1 . 
Rockaway, Oregon is just a few miles north of Tillamook Bay and is the site of a rural high school serving much of the coastal area. Some of the most important crab, shrimp and oyster fisheries along the Oregon coast are located in this area.

Ilwaco, Washington is located at the mouth of the columbia River. The high school serves grades 7 through 12 from communities located on the Long Beach Penninsula and surrounding area. Included in this area are the important Willapa Bay oyster beds, the clam beds on Iong Beach Penninsula, and the crab fisheries working out of the Columbia River estuary.

At both communities the surveys were centered at the high schools. The high school students were near-adult in size and eating habits, represented a broad cross section of the local residents and were already assembled for efficient surveying. In addition, the cooperation of local seafood packing companies was solicited and permission was obtained to contact their employees. These employees and members of their families were counted and provided diet data during off-shift hours. These latter data were representative of above-average seafood consumers. The communities involved were informed of the puxpose and nature of the survey through press releases, radio interviews and information meetings. The cooperation of the school officials, managers and owners of - seafood companies and local community officials was outstanding. A breakdown of the populations surveyed is shown in Table I. During the conduct of the first survey, a total of 462 subjects contributed diet information and were measured in the wholebody counter. Of the 462 total, 189 were surveyed at Rockaway, 
Oregon and 273 at Ilwaco, Washington. The second survey in the fall of 1971 concentrated on recounting as many as possible of those surveyed initially. There were about 60 recounts at Ilwaco out of a total of 109 counts, and at Rockaway there were about 50 recounts out of a total of 140 counts. .

TABLE I

Volunteers Included in Coastal Surveys

\begin{tabular}{|c|c|c|c|}
\hline & Rockaway & Ilwaco & Total \\
\hline \multicolumn{4}{|c|}{ April 1970} \\
\hline High School Students & 155 & 219 & 374 \\
\hline Seafood Company Employees & 14 & 26 & 40 \\
\hline Chilaren of Employees & 2 & 8 & 10 \\
\hline Other Community Adults & 18 & 20 & 38 \\
\hline Total & 189 & 273 & 462 \\
\hline
\end{tabular}

\begin{tabular}{lrrr} 
& October 1971 & & \\
\cline { 2 - 4 } High School Students & 113 & 79 & 192 \\
Seafood...Company. Employees & 10 & 21 & 31 \\
Children of Employees & 2 & 2 & 4 \\
Other Community Adults & $\frac{15}{140}$ & $\frac{7}{109}$ & $\frac{22}{249}$ \\
Total &
\end{tabular}

.The high school students obviously included some who were children of seafood workers but were not included in the later category. The group labeled "children of seafood workers" were younsters who accompanied their parents to the whole-body counter and were below the local high school age level. The division into "seafood company workers", and "other community adults" tended to be arbitrary because employment in the seafood packing plants is seasonal and includes a large number of part-time employees. Many of the "other community adults" category were teachers from the schools where the whole-body counter was located and were often 
not native to the coast.

The second survey included a smaller number of subjects in each of the categories, mostly because of lack of time to conduct a more lengthy recount. The first survey took about 2 months, the second required about 1 month.

\section{B. Whole-Body Counter Description}

The mobile whole-body counter (1) used for this study utilizes a $6 \times 111 / 2$ inch NaI scintillation crystal to detect gamma rays from radionuclides within the body. The crystal is mounted in a shadow shield assembly to reduce interference from background radiation sources. Carefully selected photo-multiplier tubes with low ${ }^{40} \mathrm{~K}$ content are used to further reduce background radiation levels. The whole-body counting data are sorted in a multi-channel, pulse-height analyzer and stored for display on an oscilloscope and recoded on either printed paper or punchpaper tape. In this study the data were first viewed on the scope and then punched on paper tape after each count. Dietary data from the survey questionnaire are coded for computer compatibility by using decade switches and an information code. These output tapes are returned to the laboratory for computer processing. The counter has been calibrated with various-size phantoms to facilitate body-burden measurements of people ranging from small children through adults. The instrument was capable of detecting a body burden of less than $1 \mathrm{nCi}$ of ${ }^{65} \mathrm{zn}$ under the low background conditions encountered at the coastal locations.

The body burden measurement requires 10 minutes for each subject followed by 2 to 3 minutes for manipulating data and 
punching the paper tape. Thus, in a normai 6-hour school day it was possible to count 20-25 students. The students were instructed in the purpose of the survey and motivated to participate in it during a special presentation made to individual classes selected to assure that' each student was contacted. These same students were then contacted again to be recounted for the second survey 18 months later.

\section{Dietary survey}

The most difficult data to obtain in a survey of this nature is accurate information concerning the seafood consumption habits of the people surveyed. Earlier surveys had used simple questionnaires (2) that relied on the memory and objectivity of the subject. Surveys of elementary school children used a technique which required the children to keep a record of their diet for a one-week period. A special questionnaire was developed to obtain information about seafood consumption for the present study. The questionnaire was designed to contain diet questions that the volunteers could answer logically, and still provide data that could be easily converted to annual ${ }^{65} \mathrm{zn}$ intake. The format used is illustrated in Figs: 4 and 5.

The subjects were first asked to determine the predominant. ways in which they prepared the four varieties of shellfish produced in the area, then they were asked to estimate how many times per year they ate those dishes.

In the case of oysters, the subjects were asked to state the number of times per year they ate them raw, in stew, fried, or in other dishes such as casseroles. Data was requested on 
the consumption rate of clams and mussels eaten steamed or fresh, as chowder, fried, or in other dishes. Inquiry about crabmeat consumption included cracked whole crab, shelled crab meat, crab sandwiches, crab cocktail, and other dishes. In the case of shrimp, questions about consumption of shelled shrimp, shrimp cocktail, fried shrimp and other dishes were asked. The number of times per year each of these seafood preparations was consumed was recorded by the volunteer in the left-hand column of the form shown in Fig. 4. To estimate the amount of each dish consumed per meal the subject was directed to one of the pages further in the questionnaire where colored pictures of five different serving sizes of each form of seafood dish were shown. The subject was asked to estimate which serving size most nearly corresponded to his own consumption habits of that form of seafood. Each of the servings shown had been weighed so that the grams of shellfish represented by each serving picture was known. Table II lists the weights of each serving size of each seafood dish used in the questionnaire. . It was not necessary to picture every possible seafood preparation because several of them were similar, e.g., oyster stew and clam chowder were estimated from the same serving size pictures.

TABLE II

Edible. Weights of Seafood Pictured in Questionnaire

\begin{tabular}{|c|c|c|c|c|c|c|}
\hline & Picture & $\underline{A}$ & $\mathrm{~B}$ & $\mathrm{C}$ & $\mathrm{D}$ & $\mathrm{E}$ \\
\hline I) & Fried Oysters (a) & 34 & 100 & 187 & 381 & 701 \\
\hline 2) & Cracked Crab & 21 & 331 & 77 & 148 & 289 \\
\hline 3) & Shelled Crab & 24 & 53 & 117 & 221 & 493 \\
\hline 4) & Fried Shrimp & 29 & 58 & 119 & 263 & 481 \\
\hline 5) & Crab Sandwich & 17 & 37 & 92 & 184 & 276 \\
\hline 6) & Shrimp cocktail & 14 & 37 & 94 & 166 & 308 \\
\hline 7) & Stewed Clams & 47 & 94 & 178 & 281 & 527 \\
\hline 8) & Clam Chowder & 40 & 88 & 172 & 272 & 404 \\
\hline
\end{tabular}


The serving sizes chosen were selected to encompass the entire range of probable consumption and this range was divided into sizes which were visually distinguishable. It was found that in the case of some seafood dishes, particularly cracked crab and stewed clams, the maximum serving shown was not nearly large enough. In these cases, the individual's questioned were instructed to indicate appropriate multiples of the maximum serving size pictured, i.e., "twice picture E", etc. This same questioning procedure was followed for both surveys conducted in the coastal communities. Those recounted during the second survey were asked to fill out an additional questionnaire. Their most recent diet habits were critical in the second survey after the

- Hanford reactors were shut down. Before the shut-down, the seafood concentrations and body-burdens were more nearly at an equilibrium level and not changing very rapidly with time. After shut-down the seafood concentrations began to decay with essentially the radioactive half-life of ${ }^{65} \mathrm{zn}$ (see Fig. 6). It then became necessary to more fully account for non-equilibrium concentrations of ${ }^{65} \mathrm{zn}$ and the dates of the seafood harvest seasons. In addition, the repeat questionnaires allowed a check on the accuracy of the survey technique.

III. Results

\section{A. Seafood Concentrations}

Samples of seafood from Tillamook Bay, Oregon and Willapa Bay, WAshington are routinely analyzed by the respective state Health Agencies for radioactive zinc $^{(3)(4)}$. Samples of oysters from 
Willapa Bay are analyzed monthly by AEC contractors as part of the Hanford Environmental Surveillance Program ${ }^{(5)}$. Additional special surveys of various organisms from Pacific coastal waters were also performed during the time both surveys were being conducted. These samples were analyzed for ${ }^{65} \mathrm{Zn}$ and some were further analyzed for total zinc content. The ${ }^{65} \mathrm{Zn}$ concentrations found in the four seafoods at the time of both studies are listed in Table III. Figure 6 illustrates ${ }^{65} \mathrm{Zn}$ concentrations found in Willapa Bay oysters analyzed at Hanford during 1970 and 1971.

\begin{tabular}{|c|c|c|}
\hline \multirow[b]{3}{*}{ Seafood } & \multicolumn{2}{|c|}{$\begin{array}{l}\text { TABLE III } \\
\text { ion of }{ }^{65} \mathrm{Zn} \text { in seafoods } \\
\text { Ilwaco }\end{array}$} \\
\hline & \multicolumn{2}{|c|}{ Concentration (pci/gm) } \\
\hline & 1970 (avg) & oct. 1971 \\
\hline Clams & 1.50 & .32 \\
\hline Crab & 3.70 & .88 \\
\hline Oysters & 10.70 & 2.24 \\
\hline Shrimp & 0.48 & .11 \\
\hline
\end{tabular}

The decrease in ${ }^{65} \mathrm{Zn}$ concentration is quite obvious after reactor shut-down. A least squares fit of the concentration data shown in Fig. 6 yielded a rate of derrease equivalent to that expected from radioactive decay alone (i.e., a half-life of 243 days).

B. Seafood Consumption

obviously the consumption of seafood by various population groups is affected by the composition of the groups and the kinds of seafood produced locally. Rockaway is located near a major crab fishery and Ilwaco is near a major oyster bed. This fact is reflected in the different consumptions between the two communities. The "students" from tiwaco include young people from grades 7 through 12, 
while those from Rockaway include only grades 1.0 through 12 . The average annual consumption of the four. seafoods obtained during the 1970 and 1971 surveys at these two communities are presented in Tables IV and $V$.

TABIE IV

Average Consumption of Seafoods by Population Groups Surveyed in Spring 1970 (Kg/year)

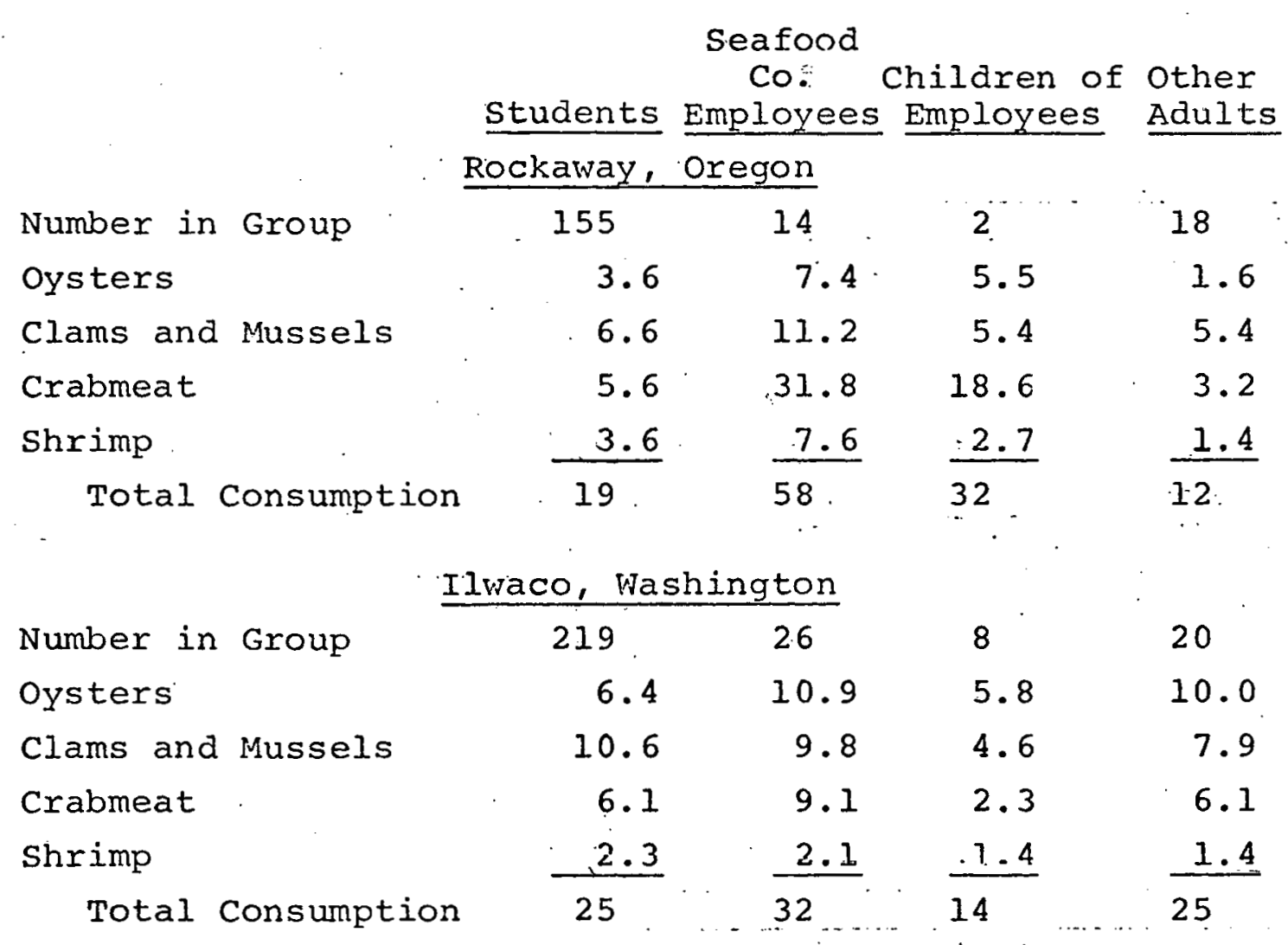

There is a large difference in consumption rate between "other adults" at Ilwaco and at Rockaway. The group from Ilwaco includes people from the washington State Oyster Laboratory who perhaps consume above average amounts of seafood. For the 1971 study, the consumption rates were generally less than those shown for the first study. The category "chilaren of employees" did not yield very significant information since only two such persons 
were counted at Rockaway and Ilwaco.

TABLE V

Average Consumption of Seafoods by Population Groups

surveyed in Fall 1971 ( $\mathrm{kg} /$ year)

\begin{tabular}{|c|c|c|c|c|c|}
\hline & & students & $\begin{array}{c}\text { Seafood } \\
\text { Co. Cl } \\
\text { Employees } \\
\end{array}$ & $\begin{array}{l}\text { hildren of } \\
\text { Employees }\end{array}$ & $\begin{array}{l}\text { Other } \\
\text { Adults }\end{array}$ \\
\hline & & Rockaway & Oregon & & \\
\hline Number in & Group & 80 & 10 & 2 & 15 \\
\hline Oysters & & 2.5 & 5.4 & & 4.2 \\
\hline Clams and & Mussels & 3.8 & 6.1 & & 8.3 \\
\hline Crabmeat & & 3.5 & 35.8 & & 15.2 \\
\hline Shrimp & & 1.6 & 9.6 & & 0.2 \\
\hline Total & Consumption & 11 & 57 & & 28 \\
\hline & & Ilwaco, Wo & ashington & & \\
\hline Number in & Group & 55 & 20 & 2 & 7 \\
\hline Oysters & & 4.7 & 12.7 & 11.4 & 13.8 \\
\hline Clams and & Mussels & 8.5 & 12.8 & 7.5 & 20.9 \\
\hline Crabmeat & & 3.9 & 6.2 & 1.7 & 4.0 \\
\hline Shrimp & & 3.1 & 2.6 & 0.0 & 0.8 \\
\hline Total & onsump & 20 & 34 & 21 & 40 \\
\hline
\end{tabular}

The total consumption values listed in Tables IV and $\mathrm{V}$ can be compared with the results of surveys at an inland city (Richland, Washington) where the average annual seafood consumption was $1.2 \mathrm{~kg} / \mathrm{yr}$ for adults and $0.9 \mathrm{~kg} / \mathrm{yr}$ for teenagers.

Distribution of consumption ratios obtained in 1970 for the four seafoods within the student and employee populations of the two communities are illustrated in Figs. 7 through 10. These figures also show the distributions of the ${ }^{65} \mathrm{zn}$ body burdens among the population groups. The consumption distributions for 
the four seafoods determined from the fall 1971 survey are essentially identical to those shown for the spring 1970 survey even though only about half as many people participated in the later study. This similarity implies that the techniques used to obtain the consumption data yields consistant results. The distributions of ${ }^{65} \mathrm{Zn}$ body burdens for the fall 1971 study are also quite similar to those obtained during the 1970 study. However, the earlier study showed more individuals with body burdens greater than $4 \mathrm{nCi}$ of ${ }^{65} \mathrm{zn}$. Average body burdens for the students are smaller in the fall of 1971 as shown in Fig. 11 but are still somewhat higher than expected on the basis of radioactive decay of ${ }^{65} \mathrm{zn}$ in the seafoods. The average body burden in Ilwaco students decreased only about 50\% while the average body burden "for Rockaway students decreased only about $30 \%$ over the 18 months between the studies.

To obtain some idea of how well the model for uptake of ${ }^{65} \mathrm{Zn}$ fits the population studied, the ratios of measured-to-calculated ${ }^{65} \mathrm{zn}$ body burdens were determined. This information is shown in Fig. 12 for Rockaway and Ilwaco students for both the spring 1970 and the fall 1971. studies. For the 1970 survey, the average ratio was between 1.0 and 2.0 , indicating that either the students under-estimated their intake of seafood or the intake parameters (fractional uptake, $f_{W}$, and effective half-life, $T_{\text {eff }}$ ) used for this population are slightly in error. The Teff used was 194 days as given by ICPRP, Publication \#2 (6). However, different values of $f_{w}$ for each of the seafoods were determined by a least squares fit of the data. 
For the fall 1971 studies, the measured-to-calculated ${ }^{65} \mathrm{zn}$ body burden ratios for students are larger than the ratios for the 1970 study. At Ilwaco the ratio is about 2.0 , and at Rockaway the ratio is about 4.0 . The distribution obviously is skewed to the high end by a number of people who either grossly underestimated their seafood intake or had some other source of ${ }^{65} \mathrm{zn}$ in their diets. If the ratios greater than 5 are deleted, the average ratios are much more reasonable. The average ratio for Ilwaco then is about 1.0 and for. Rockaway is about 2.0 .

IV. CONCLUSIONS

The distributions of the ratios between the measured and calculated ${ }^{65} \mathrm{Zn}$ body burdens are somewhat flat and not centered on 1.0. However, they could well be typical of data of this type obtained from the general population. Some of the scatter is undoubtedly due to inaccuracies in the recalling seafood consumption, and some is quite likely due to real variations in uptake and retention of ${ }^{65} \mathrm{zn}$ between individuals. Particularly, the retention of ${ }^{65} \mathrm{zn}$ may be a function of the amount of stable zinc already in the body. Persons with low body burdens of stable zinc may pick up and retain higher levels of radioactive zinc, and vice versa. The effective half-life of any radionuclide certainly varies from one person to another because of differences in body metabolism. Considering the many variables, agreement within a factor of two ketween the measurements and calculations is a reasonable result. Further studies are planned for the fall of 1972 . 


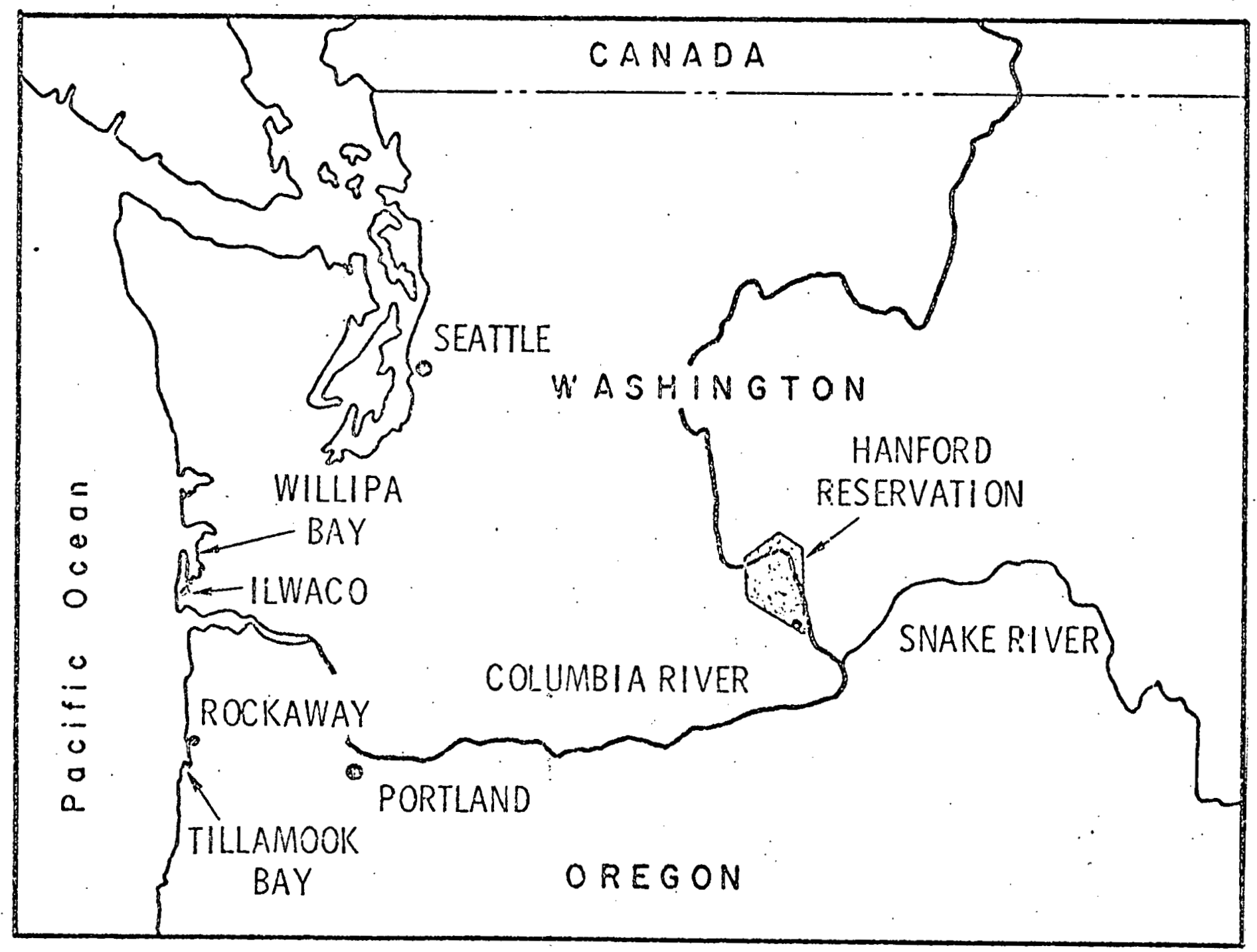

Fig. 1. Location of Hanford and Seacoast Communities 


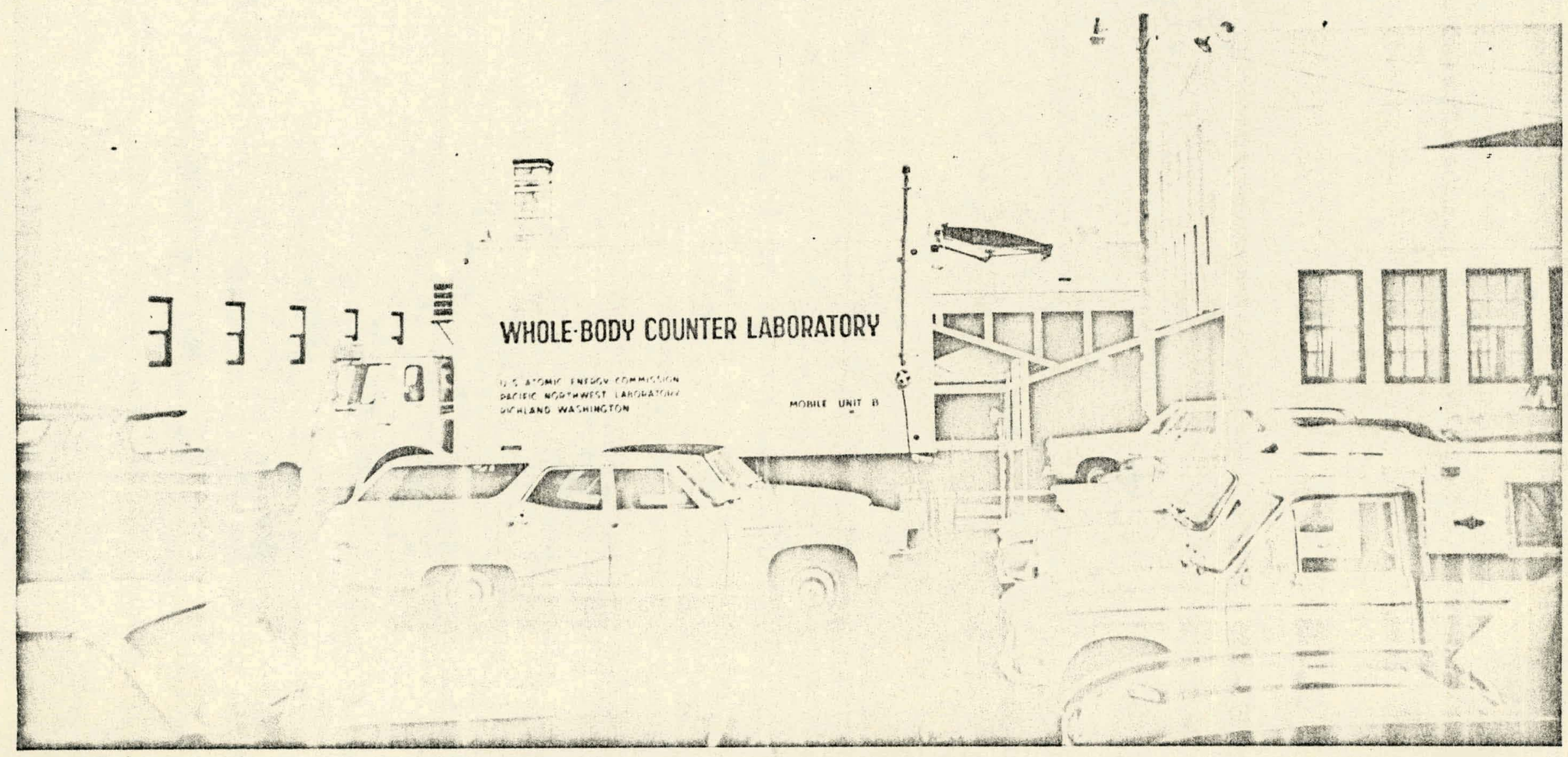




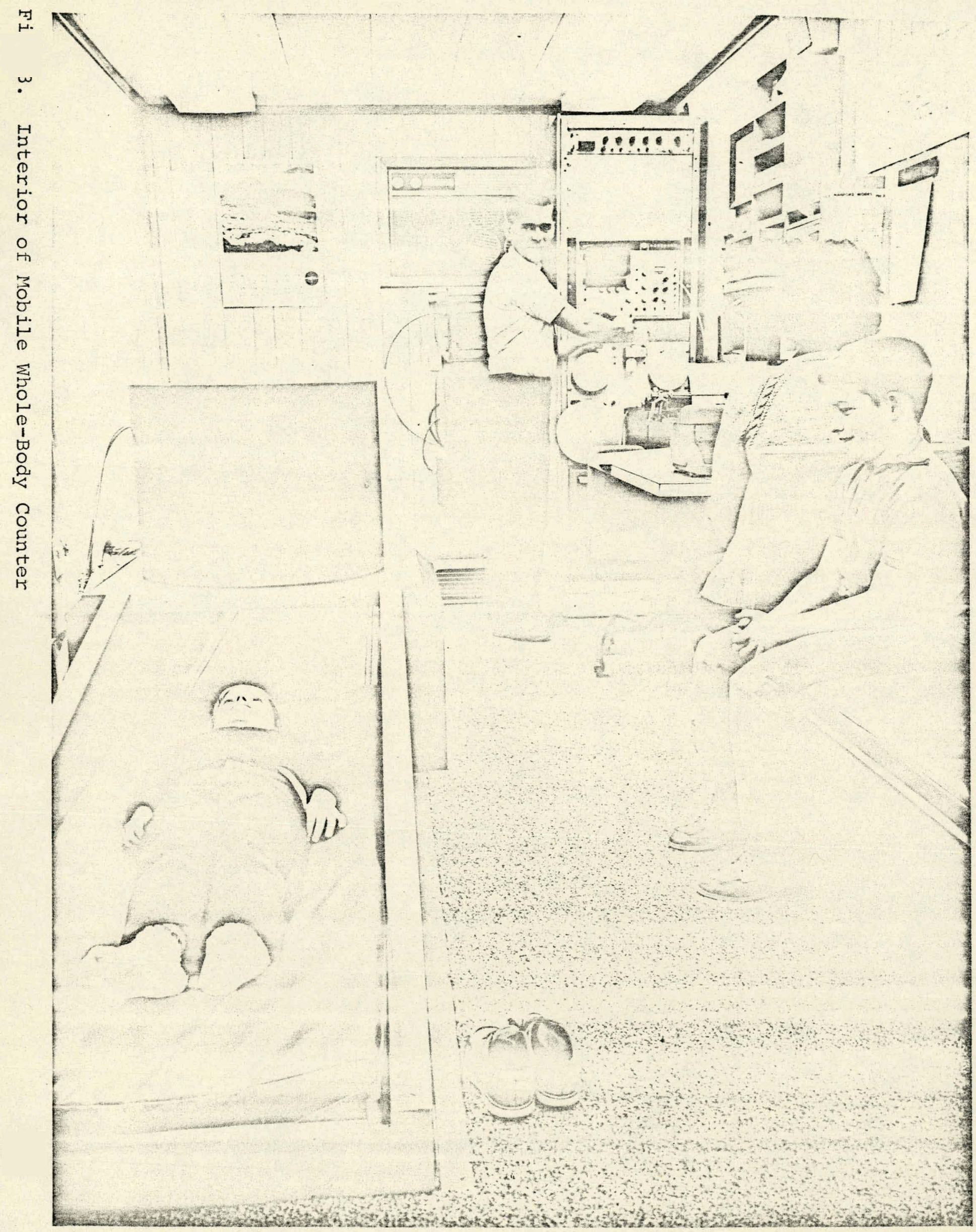


Estimates of how much seafood produced in this area $I$ eat in a year:

\section{ABOLT HOW MANY ABOLT HOW MUCH IS \\ TIMES A YEAR? EATEN EACH TIME?}

Oysters

Fresh (uncooked)

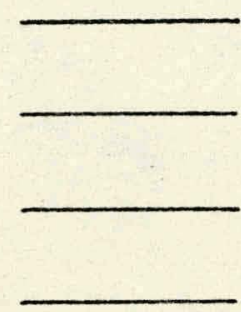

(No. of oysters)

Stew

Fried

Other

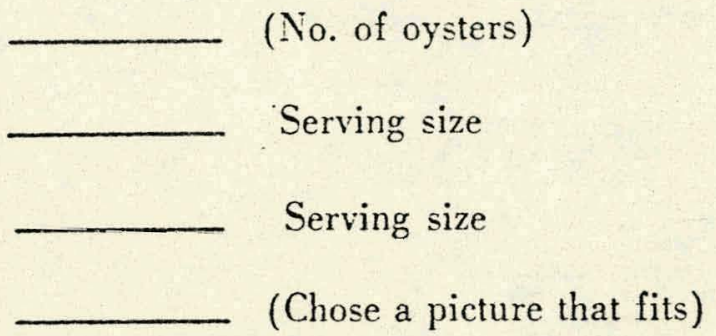

Clams \& . Mussels

Steamed or fresh

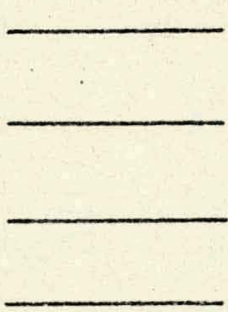

Serving size

Chowder

Fried (or patties)

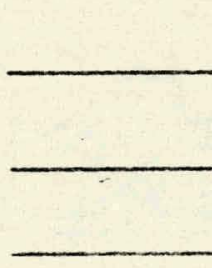

Serving size

Other

Serving size

(Chose a picture that fits)

Crab

Cracked whole

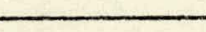

Crabmeat (in Louis',etc.)

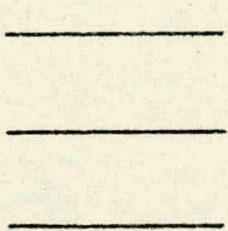

Cocktail

Other

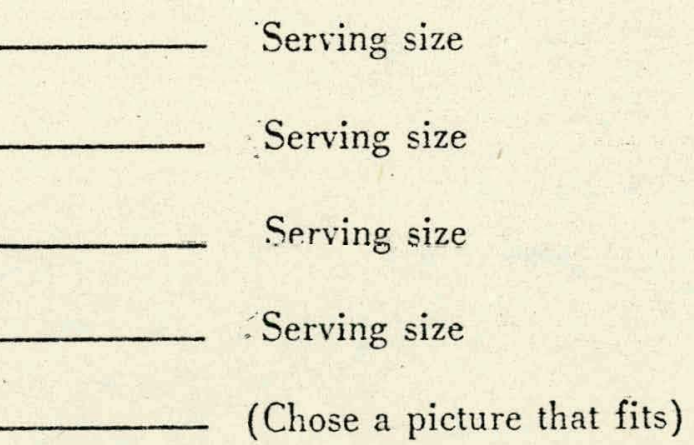

Shrimp

Shelled (in Louis', etc.)
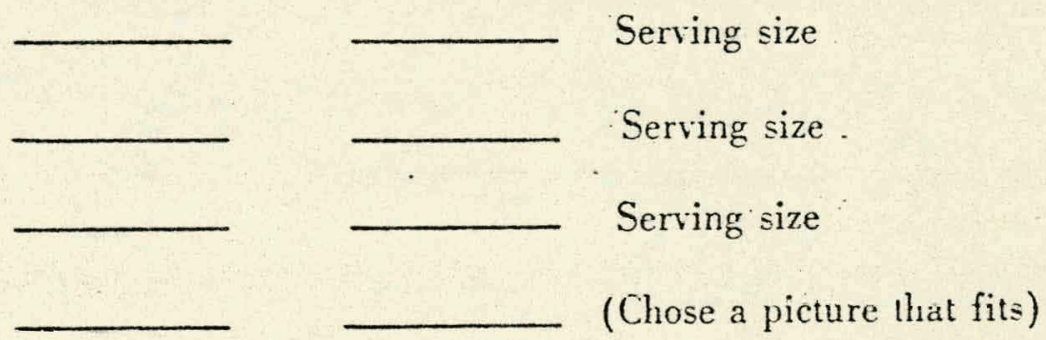
Do you sometimes collect seafood for your own use?

What kinds have you obtained in this way during the past year?

•

How much of the seafood you eat is collected by other than a commercial fishery?

(Please check appropriate box)

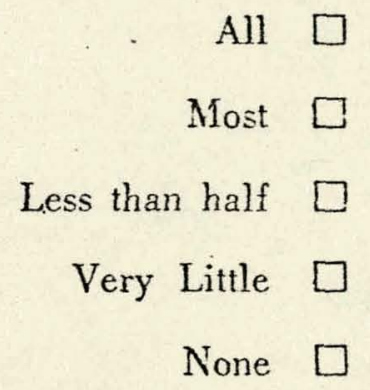

Other Comments:

Fig. 5. Seafood Intake @uestionnaire 
Fig. 6. ${ }^{65} \mathrm{Zn}$ Concentration in Villapa Bay Oysters

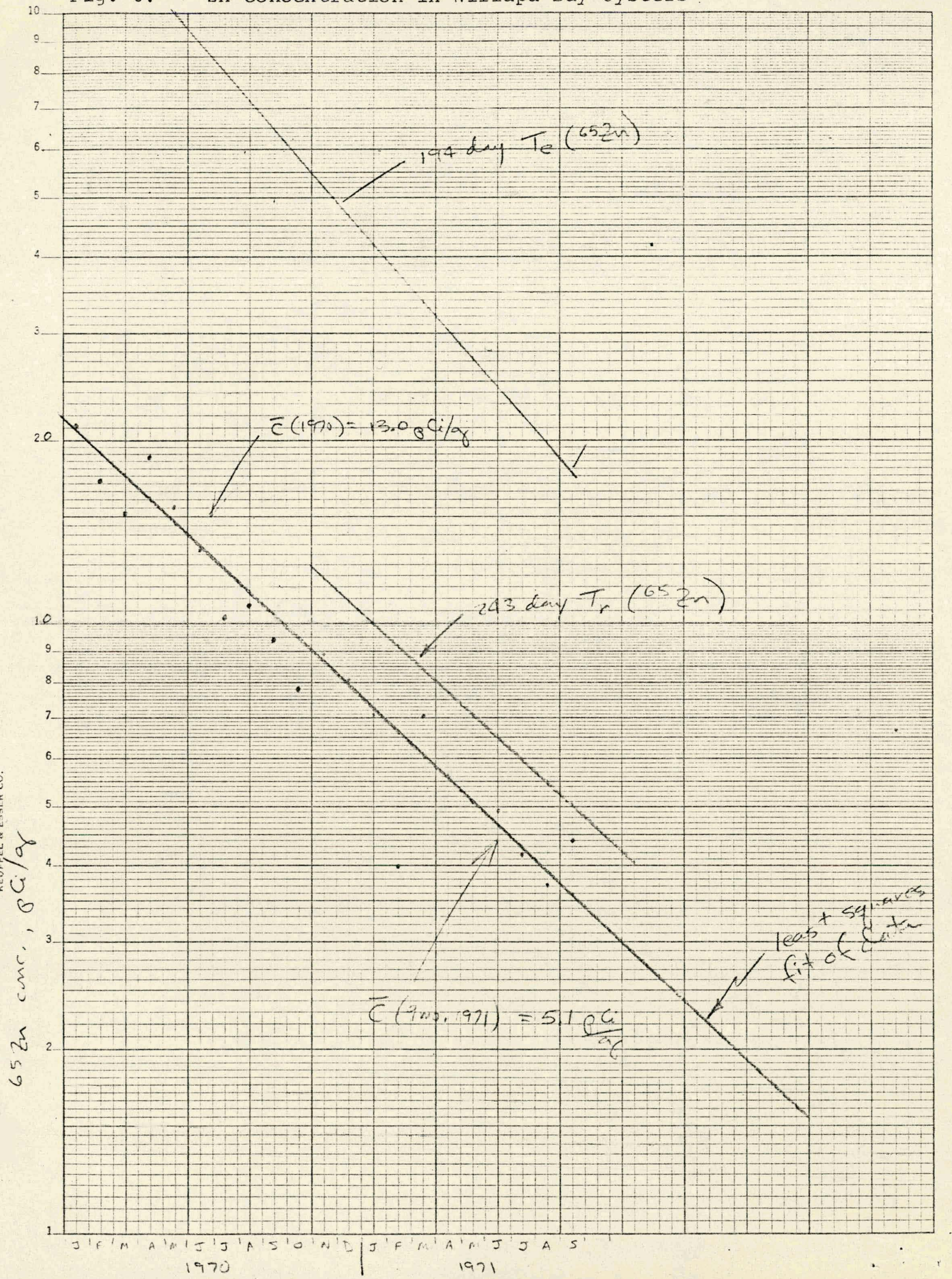


Fig. 7. Distributions of SEAFOOD CONSUMPTION AND ${ }^{65}$ Zn BODY BURDENS, HIGH SCHOOL STUDENTS, ROCKAWAY, OREGON, 1970 TOTAL CASES $=155$
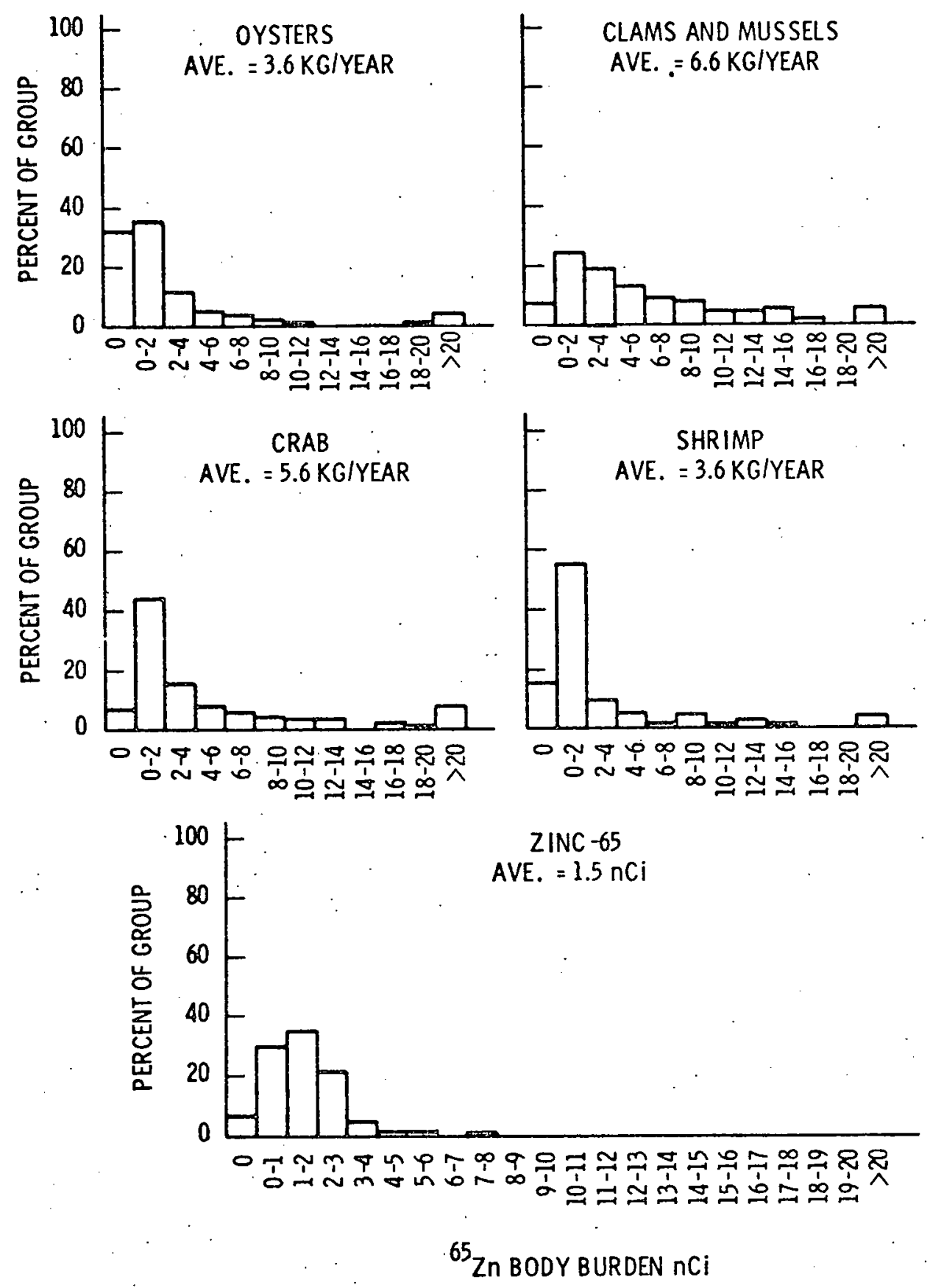

Fig. 7. 
Fig. 8. Distributions of SEAFOOD CONSUMPTION AND ${ }^{65} \mathrm{Zn}$ BODY BURDENS, HIGH SCHOOL STUDENTS, ILWACO, WASHINGTON, 1970 TOTAL CASES $=219$
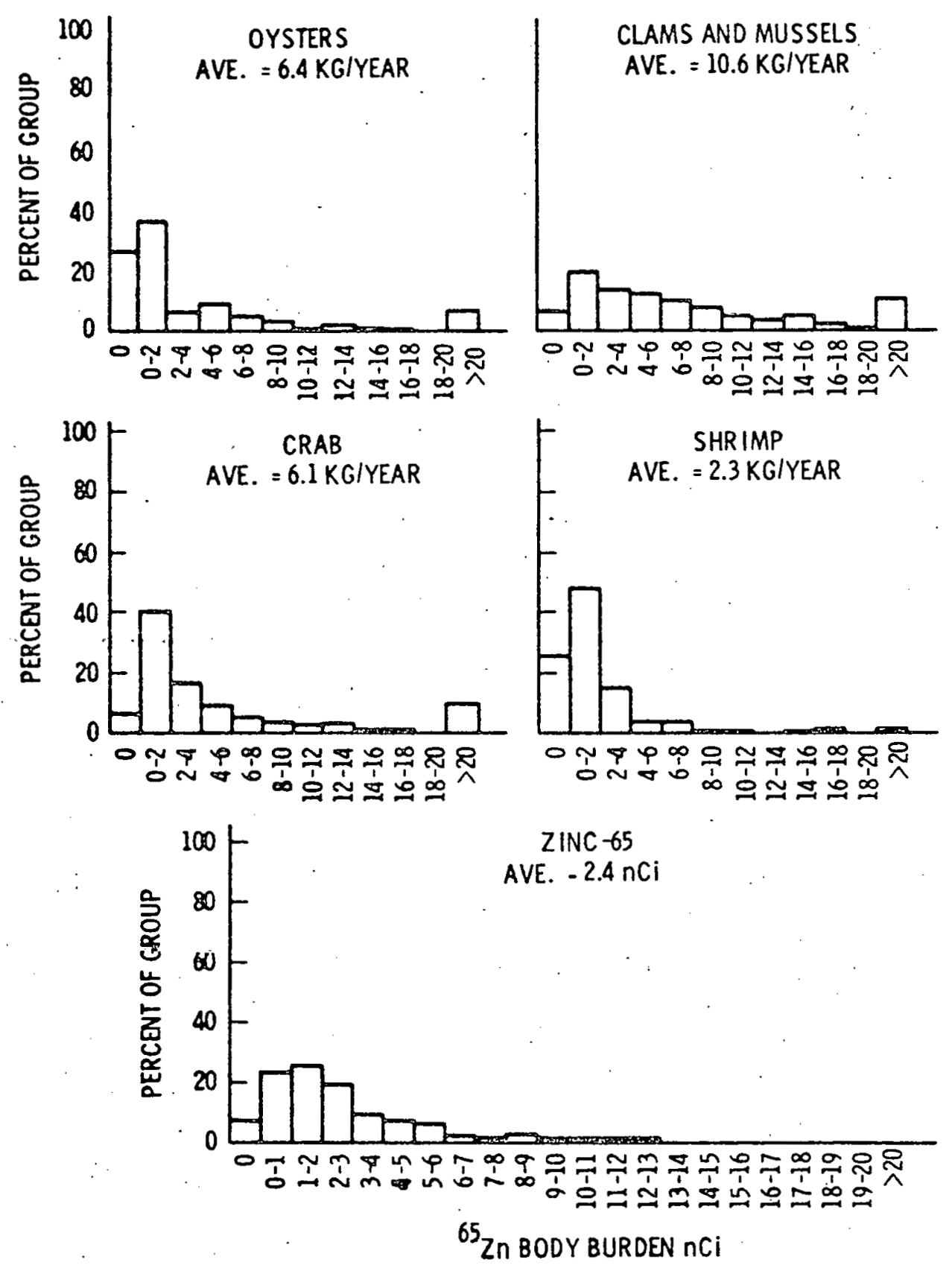

Fig. 8 
Fig. 9. Distributions of SEAFOOD CONSUMPTION AND ${ }^{65} \mathrm{Zn}$ BODY BURDENS, SEAFOOD WORKERS, ROCKAWAY, OREGON, 1970 TOTAL CASES $=14$
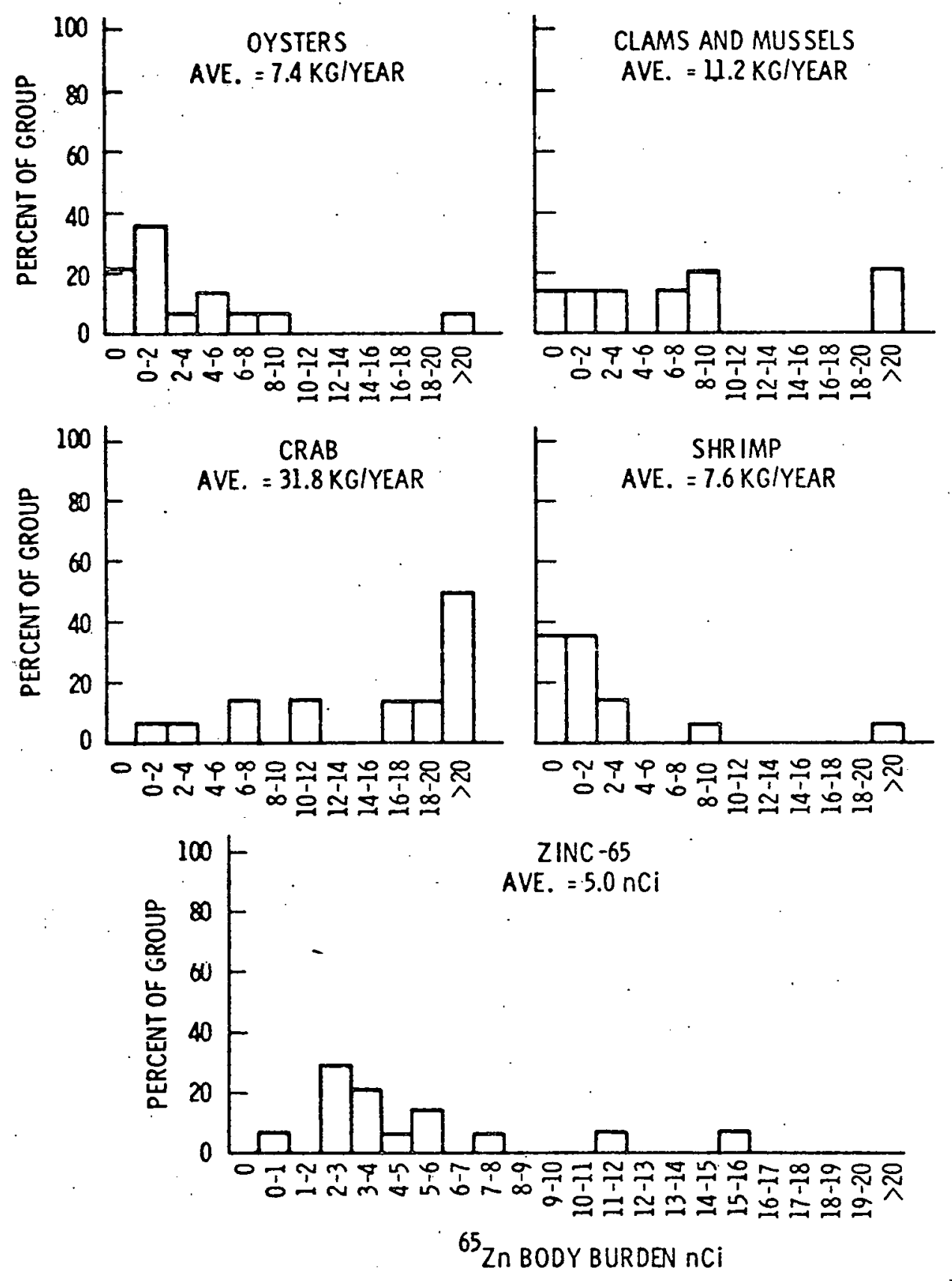

Fig. 9 
Fig. 10. Distributions of SEAFOOD CONSUMPTION AND ${ }^{55} \mathrm{Zn}$ BODY BURDENS,

SEAFOOD WORKER.S, ILWACO, WASHINGTON, 1970 TOTAL CASES $=26$
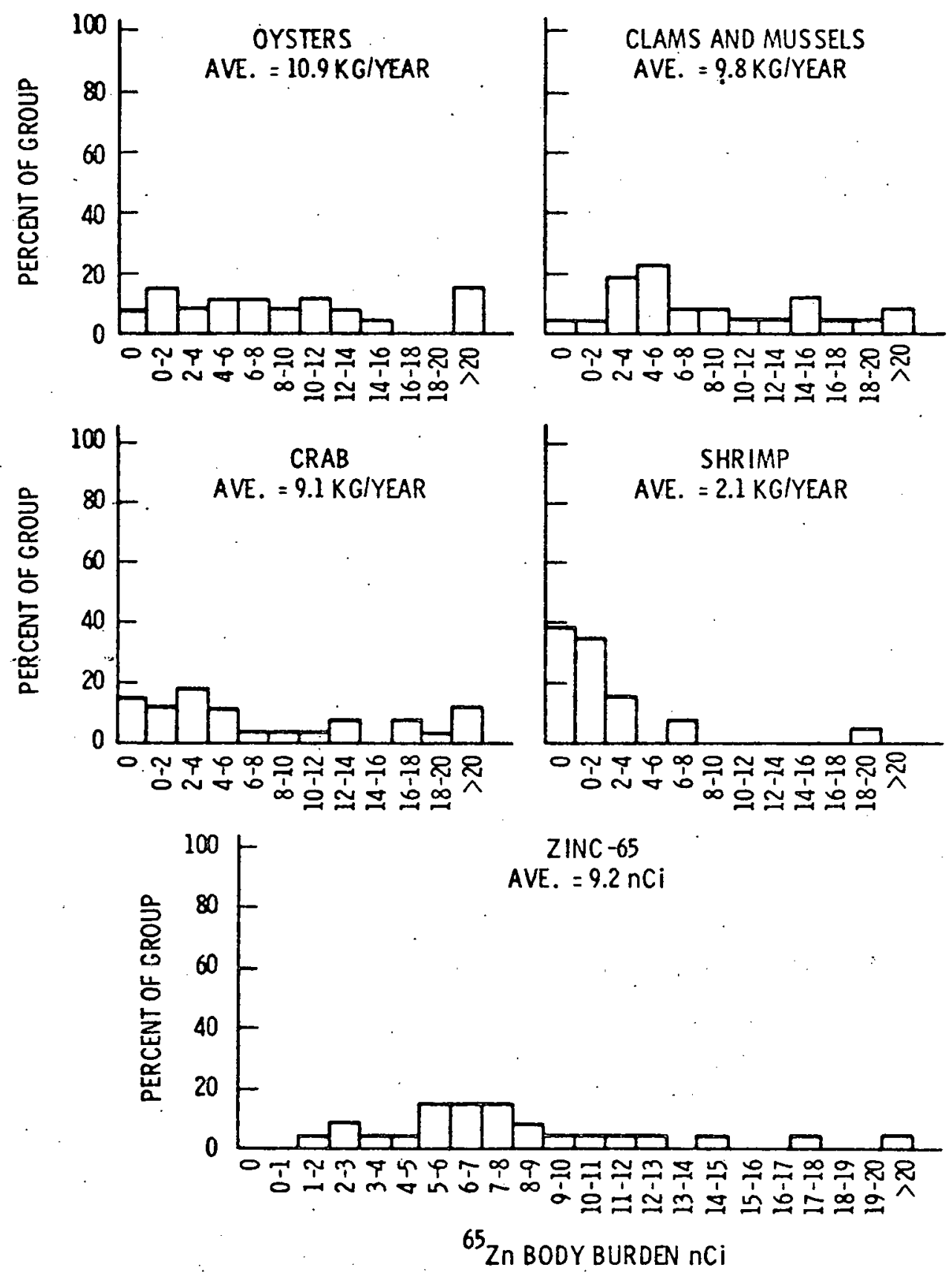

Fig. 10 
Fig. 11. Distributions of ${ }^{65} \mathrm{Zn}$ Body Burdens, 1971
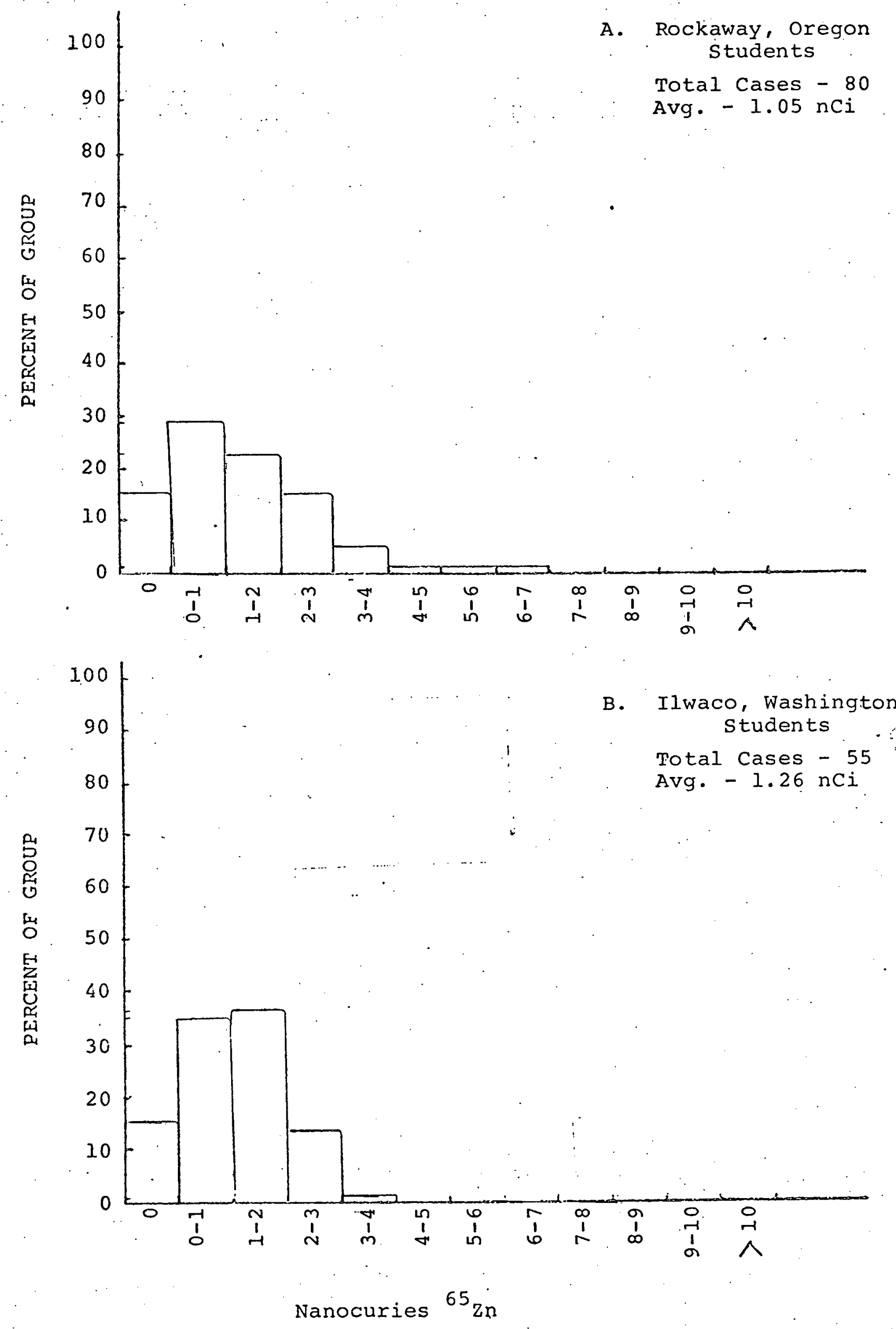
Fig. 12. Measured-to-Calculated Ratios of ${ }^{65} \mathrm{Zn}$. Body Burdens - Seacoast students

Rockaway students

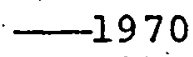

---1971

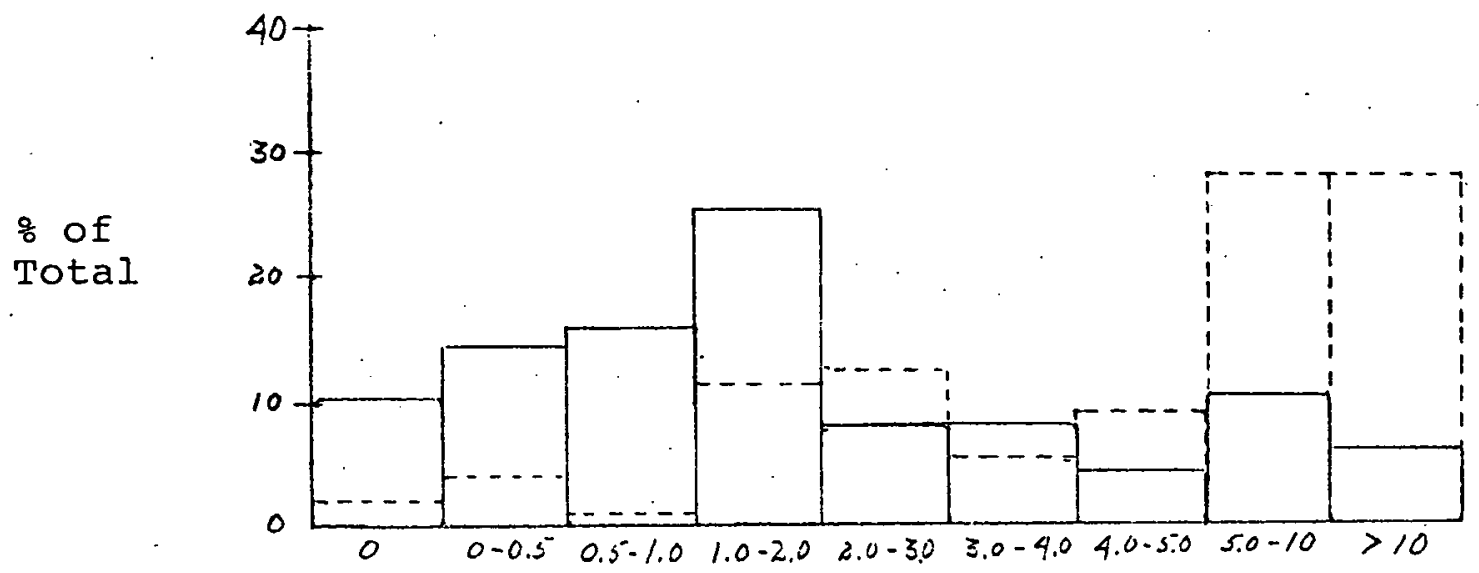

Ilwaco Students

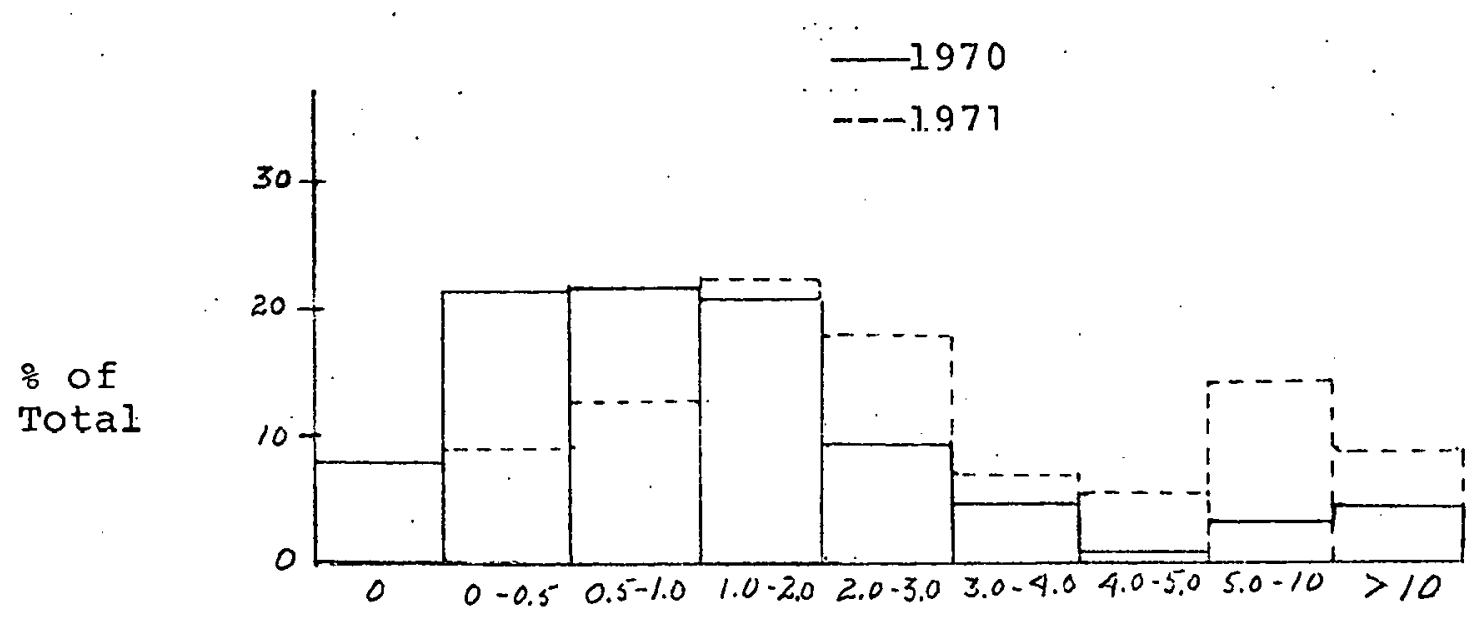

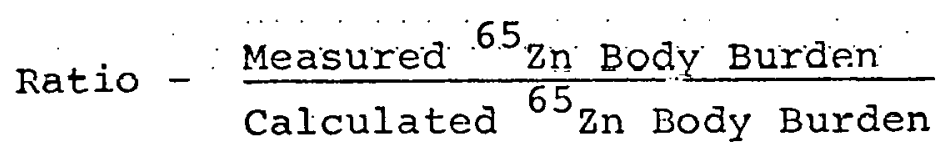




\section{REFERENCES}

1) F. N. Eichner, "Whole Body Counter Laboratory Mobile Unit B, Description and Operation." BNWL-1154, Aug. 1969.

2) J. F. Honstead, "A Program for Evaluating Environmental Radiation Dose to Children.". BNWL-SA-1051, June 1967.

3) G. L. Toombs and P. B. Culter, "Lower Columbia River Environmental Radiological survey in oregon." Oregon state Board of Health, Feb. 1968 .

4) R. R. Mooney, "Environmental. RAdiation Surveillance in Washington State, Quarterly Reports, Division of Health, Department of Social and Health Services.

5) "Evaluation of Radiological Conditions in the Vicinity of Hanford for 1969." Environmental Evaluations Staff, C. B. Wilson and T. H. Essig, ed. BNWL-1505, Nov. 1970.

6) International Commission on Radiological Protection. Recommendation of the International Commission on Radiological Protection. Report No. 2, Pergamon Press, New York, NY, 1959. 